\title{
Lingulate brachiopods from the Acanthopyge Limestone (Eifelian) of the Barrandian, Czech Republic
}

\author{
MICHAL MERGL
}

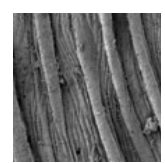

\begin{abstract}
The lingulate brachiopod fauna of the mid-Devonian Acanthopyge Limestone, Choteč Formation of the Prague Basin, Czech Republic comprises seven species, of which Kosagitella pulsatilla sp. nov., Microbolus minimus gen. et sp. nov., Chynithele amoena sp. nov., and Opatrilkiella kobyla sp. nov. are described as new. Shell microornaments of all taxa are examined. The pitting on the mature shell of Kosagitella, and diverse types of pitting on discinid shells have been observed, including the imprints of suggested siliceous tablets on the first-formed shells of Acrosaccus and Opatrilkiella. - Key words: Barrandian, Silurian, Devonian, lingulid, glosseline, brachiopod, taxonomy, Czech Prague Basin.
\end{abstract}

MERGL, M. 2009. Lingulate brachiopods from the Acanthopyge Limestone (Eifelian) of the Barrandian, Czech Republic. Bulletin of Geosciences 83(3), 281-298 (10 figures). Czech Geological Survey, Prague. ISSN 1214-1119. Manuscript received August 4, 2008; accepted in revised form September 5, 2008, issued September 30, 2008.

Michal Mergl, Department of Biology, Faculty of Education, University of West Bohemia in Plzeň, Klatovská 51,30619 Plzeň, Czech Republic; mmergl@kbi.zcu.cz

The evolutionary history of the lingulate brachiopods in the Devonian is less clear compared with our knowledge of the history of this group in Cambrian and Ordovician times. The reason is paucity and low diversity of the lingulate shells in the fossil record, making this group less attractive for taxonomical studies. However, a careful search for beds bearing lingulate brachiopods in rocks of Silurian and Devonian age has already brought useful results (Mergl 2001, Valentine 2006).

A new search for lingulate brachiopods in the Devonian of the Prague Basin has resulted in the discovery of a remarkably diverse lingulate fauna in the Acanthopyge Limestone (Eifelian) in the Koněprusy area. A peculiar new micromorphic glosselline has been observed and is described below.

\section{Geological setting of the Acanthopyge Limestone}

With the beginning of the Pragian, a massive reef complex appeared in the Koněprusy area of the Prague Basin, at present situated some $30 \mathrm{~km} \mathrm{SW}$ from Prague (Fig. 1). The richly fossiliferous Koněprusy Limestone built the core of the reef and the surrounding talus. After marine abrasion of the reef top in the early Emsian, the reef flat was flooded, and new sedimentation of the mostly reddish crinoidal $\mathrm{Su}-$ chomasty Limestone took place in the late Emsian. A favourable shallow water environment continued into the Ei- felian. The top of the elevation provided an excellent site for the growth into local biostromes of diverse corals, stromatoporoids, crinoids and brachiopods. Local accumulations of washed and slumped material formed the grey and pink Acanthopyge Limestone, now preserved in a small area between Zlatý Kůn̆ and the Kobyla hills near Koněprusy.

The Acanthopyge Limestone is a local member of the Choteč Formation, representing the Eifelian up to the Eifelian-Givetian boundary. The age is confirmed by the conodonts Polygnathus costatus partitus, P. costatus costatus, Tortodus kockelianus australis, T. kockelianus kockelianus, and P. xylus ensensis zones (Zikmundová \& Kalvoda 1991, Chlupáč 1998). Chlupáč (1957, 1959) and Havlíček \& Kukal (1990) examined the lithology and stratigraphy of the Acanthopyge Limestone, and Galle \& Hladil (1991) and Hladil et al. (1992) presented detailed stratigraphical successions for the Jirásek, Preisler and Červený quarries. Trilobites, brachiopods and corals are the most important groups in the limestone, having been studied by several authors since the mid $-19^{\text {th }}$ century and revised in the last decades (Chlupáč 1977, Šnajdr 1980, Hladil 1993). Trilobites Phacops (Chotecops) hoseri (Hawle \& Corda, 1847), Acanthopyge haueri (Barrande, 1846), Thysanopeltis speciosa (Hawle \& Corda, 1847), and diverse proetids form a characteristic Acanthopyge-Phaetonellus Assemblage (Chlupáč 1983). Rhynchonelliformean brachiopods have been revised by Havlíček \& Kukal (1990); they are mostly represented by 


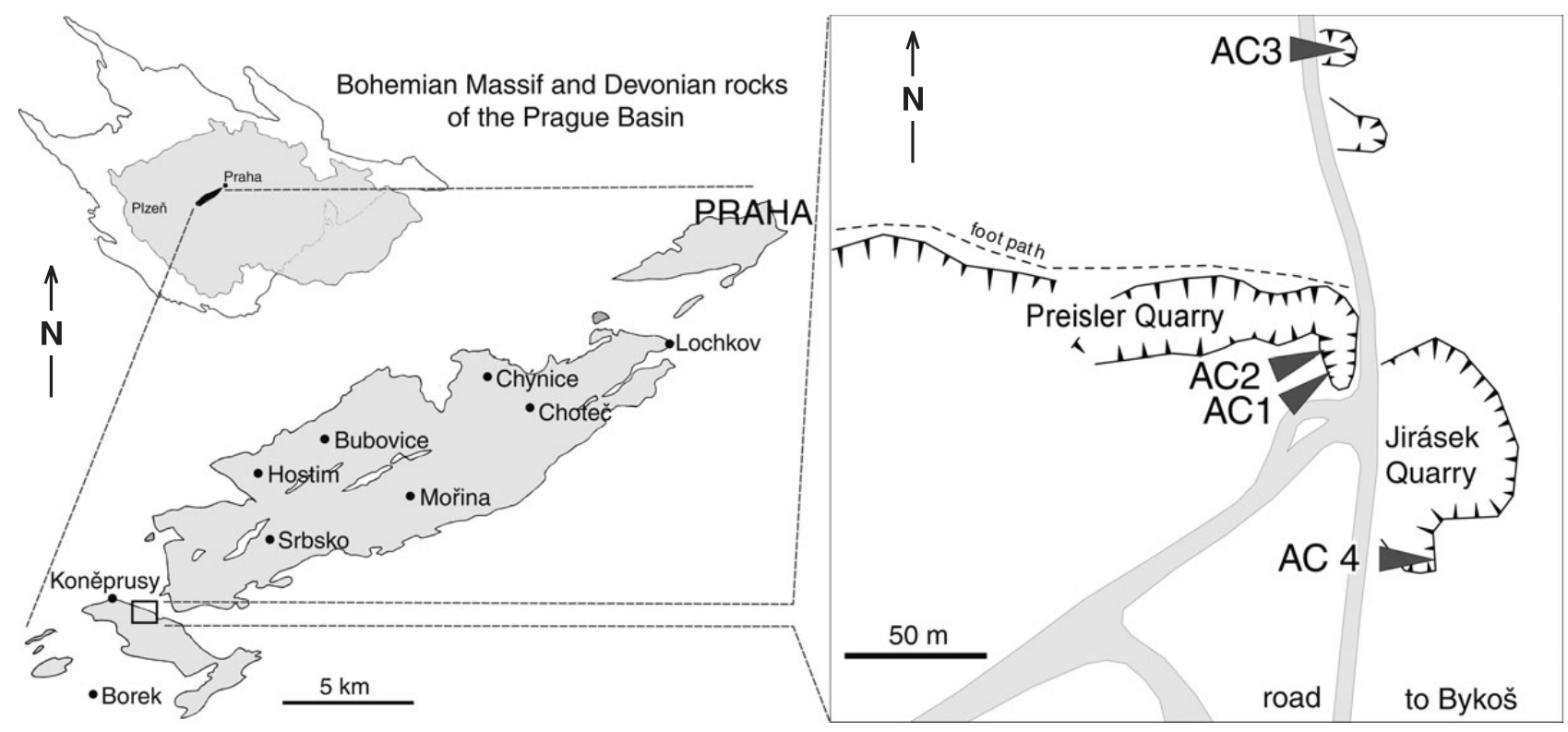

Figure 1. Sketch map of the classic Barrandian Silurian and Devonian of the Prague Basin, and of quarries near the Bykoš - Koněprusy road with location of the samples AC1-AC4.

small- and medium-sized taxa with smooth or weakly costate shells and, in total, 28 rhynchonelliformean taxa reported. Unlike the rhynchonelliformeans, the lingulate brachiopods have never been examined and only Chynithele ventricona Havlíček, 1996, and Kosagitella (?) lingua (Barrande, 1879) have been reported (Mergl 2001).

\section{Material and methods}

Brachiopods have been sampled from several layers of grey bioclastic limestone with abundant exoskeletal parts of Phacops (Chotecops) hoseri, corals, smooth-shelled brachiopods, and other less common fossils. A bed with fossils probably represents a debris flow deposit, but breakage is not significant being evidenced by a prevalence of complete brachiopod shells. The spaces between large bioclasts have been filled with grey micritic limestone and shell debris. Empty spaces, exemplified by free cavities inside shells, were subsequently filled by crystalline calcite. Abundant and diverse conodonts indicate the Polygnathus costatus costatus Zone (lower Eifelian).

Four samples have been examined (Figs 1,2). The main sampled limestone beds (samples AC1, AC2) are exposed on a low eastward-facing slope of a small quarry known as Preisler Quarry, just near the west (left) side of the road from Bykoš to Koněprusy, opposite the famous Jirásek Quarry (also called “Acanthopyge Quarry”) (Figs 1, 2). Preisler Quarry is also known as the "small quarry" or locality No. 10 in Havlíček \& Kukal (1990). The sampled beds lie below the measured section of Galle \& Hladil (1991), and correspond to the middle part of the
Acanthopyge Limestone, most probably to the upper part of the Polygnathus costatus costatus Zone.

Dissolving samples AC1 and AC2 (ca $30 \mathrm{~kg}$ of limestone in total) with $10 \%$ dilute acetic acid yielded several tens of phosphatic shells that are white in colour and extremely fragile. In the residues small fragments prevail over more complete parts of shells. This fragmented state of preservation likely results from etching of the rock. No abraded shells have been observed. Excluding micromorphous taxa complete valves are very rare; only one complete bivalved brachiopod shell has been observed. Some shells show desquamation of the superficial layers or exfoliation of the first-formed shell. Despite this mode of preservation, the shells show many important details, including microornament of the first-formed and mature shells. An irregular polygonal net is seen on the surface of some shells, but this net is unrelated to original shell morphology and represents imprints of calcite crystals of the adjacent rock.

Two other samples AC3 and AC4 have been examined for comparative purposes. AC3 from a small quarry northwards on the opposite side of the road (90 m to N of Preisler Quarry), and AC4 from Jirásek Quarry demonstrate the uniformity of the lingulate brachiopod fauna in the Acanthopyge Limestone. The same taxa (Kosagitella, Microbolus, Chynithele, Opatrilkiella) have been observed, but small shell fragments indicate the presence of other but much rarer discinids (one or two species) in sample AC3. In total, seven species of lingulid brachiopods have been surely determined. This indicates that other lingulate brachiopods are extremely rare and sample diversity corresponds to the original lingulate brachiopod diversity. Apart 
from the brachiopods, samples AC1-AC3 contain abundant, diverse conodonts, acanthodian bones, fragments and holdfasts of conulariids and spines of crustaceans. Lingulate brachiopods as well as other phosphatic microfauna are very rare in the white sparitic crinoidal limestone (sample AC4) outcropping in a low southeast wall of Jirásek Quarry, which lies below the main sampled beds.

\section{Repository}

All specimens including the types are housed in the palaeontological collections of the Department of Biology in the University of West Bohemia in Plzeň, Czech Republic (catalogue numbers PCZCU 1714-1738).

\section{Systematic part}

Order Lingulida Menke, 1828 sensu Waagen, 1885

Family Obolidae King, 1846

Subfamily Obolinae King, 1846

\section{Genus Kosagitella Mergl, 2001}

Type species. - Kosagitella clara Mergl, 2001; Kopanina Formation, Ludlow, Silurian; Barrandian, Czech Republic.

Remarks. - The microornament of the brephic and mature shell was unknown when the original definition of the genus Kosagitella was defined (Mergl 2001). The recently observed microornament consists of regular subhexagonal uniformly-sized hemispherical pits (Fig. 3C, Q). It is similar to the pitting described in Wahwahlingula antiquissima (Jeremejew, 1856) by Cusack et al. (1999) and Popov et al. (2002), and in W. sevierensis Holmer et al. 2005 by the authors. The size of the pits in Kosagitella is $2-3 \mu \mathrm{m}$. Holmer et al. (2005) suggested that pits of this size might be interpreted as imprints of proteinaceous vesicles (Williams 2003). Pitting of a different type has been observed in $\mathrm{Obo}$ lus eichwaldi by Cusack et al. (1999). It differs from the pitting of Kosagitella in being composed of semicylindrical, posteriorly-inclined larger pits and intercalated smaller hemispherical pits. The pitting of hemispherical pits on the mature shell is also present in the Ordovician glosselline Pachyglosella Cooper, 1960 (Holmer \& Popov 2000, Popov 2000). According to the redefinition of the family Zhanatellidae Koneva, 1986 by Holmer \& Popov (2000), the pitted microornament of the mature shells supports a re-assignment of Kosagitella and Pachyglosella to the Zhanatellidae. However, the pitted microornament of zhanatellids is not uniform but instead, scattered circular hemispherical pits (Rowellella Wright, 1963, Wahwahlingula Popov et al., 2002, Zhanatella Koneva, 1986), regular

\section{Lower-Middle Devonian succession in the Koněprusy area}

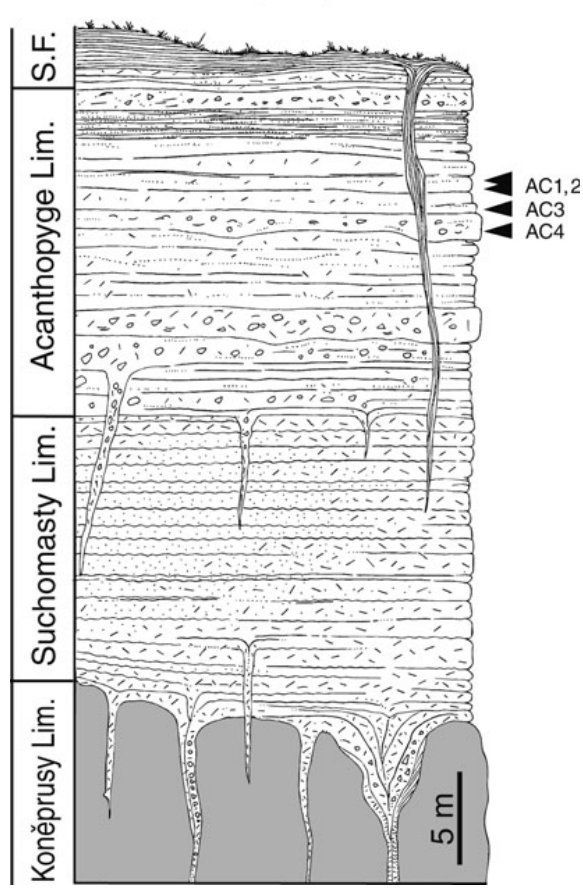

Figure 2. A - generalised stratigraphy of the Pragian (Koněprusy Limestone), Emsian (Suchomasty Limestone), Eifelian (Acanthopyge Limestone), and Givetian (top of the Acanthopyge Limestone and the Srbsko Formation) in the Koněprusy area with marked neptunic dykes and approximate positions of samples. Modified after Chlupáč et al. (1986) and Hladil et al. (1992). • Photo showing the west slope of Preisler Quarry with detailed positions of samples AC1 and AC2 (January 2008), available as an electronic supplementary material.

transverse pits (Rosobolus Havlíček, 1982), and irregularly-arranged elongate to rounded to pits (Thysanotos Mickwitz, 1896) (Cusack et al. 1999) are found. Other characteristic but different microornament of flat-bottomed rhomboidal to lenticular pits is known in paterulids, elkaniids and aulonotretids (Cusack et al. 1999, Holmer \& Popov 2000, Williams 2003). These different pits, interpreted as imprints of mineralized tablets (Williams 2003) are unknown in Kosagitella.

Kosagitella has a distinct dorsal pseudointerarea, which precludes its assignment to glossellines and it should therefore be referred to the family Zhanatellidae. However, zhanatellids were supposed to be extinct by the end of the Ordovician (Holmer \& Popov 2000). However, contrary to Holmer \& Popov (2000), I suggest that pitted microornament has been present in more evolutionary groups, including taxa with and also without a dorsal pseudointerarea. Consequently, the concept of the family Zhanatellidae needs revision, and herein the family is considered polyphyletic. It does not accommodate Silurian to Mid-Devonian Kosagitella, which more probably belongs to another yet undefined clade. 


\section{Kosagitella pulsatilla sp. nov.} Figure 3

2001 Kosagitella(?) lingua (Barrande, 1879). - Mergl, pp. 12,13 , pl. 3, figs $16-18$.

Holotype. - Dorsal valve, PCZCU 1716 (Fig. 3A, B, D).

Paratype. - Incomplete ventral valve, PCZCU 1717 (Fig. 3E, F, P).

Type horizon. - Eifelian, Acanthopyge Limestone, Polygnathus costatus costatus Zone.

Type locality. - Preisler Quarry near road Bykoš - Koněprusy, Koněprusy, central Bohemia.

Name. - After Pulsatilla pratensis, a characteristic flower at the type locality.

Material. - One complete dorsal and two complete ventral valves, ten incomplete valves and numerous small fragments.

Diagnosis. - Small, strongly-biconvex Kosagitella shell of elongate oval outline, with rounded posterior margin, short ventral pseudointerarea, and weakly-impressed pallial markings.

Description. - The shell is biconvex and fairly thickwalled relative to shell size, $4.7 \mathrm{~mm}$ long in the largest complete ventral valve. The dorsal valve is elongate oval, $130 \%$ as long as wide in the single preserved complete shell, having a slightly pointed apex. The sides and anterior margins are evenly rounded, with the anterior third of the shell regularly semicircular in outline. The maximum width is located between the midlength and the anterior third. The valve is gently and evenly convex transversally and axially. The posterior margin of the first-formed shell forms the ventrally facing posterior margin of the valve.

The dorsal interior shows a distinct median groove of broadly triangular outline resting on the steeply-sloping posterior floor of the valve, with a low shortly-excavated anterior edge. Fine raised diverging lines, crossing each another along the shell axis, cover its surface. The propareas are undivided, very narrow and essentially restricted to the posterolateral shell edge. The propareas are not distinctly separated from the median groove. The visceral area is poorly defined. It rests on a steeply-sloping valve floor posterolaterally, bounded by a pair of elongate, undivided and anteriorly-expanding scars of transmedian, outside lateral and middle lateral muscles. The central muscles are weakly impressed in the one-third between the shell axis and the lateral margins.

The ventral valve has an outline similar to the dorsal valve but having a more pointed apex. The large complete valve is $135 \%$ long as wide, with maximum width located slightly anterior to midlength. The larval shell clearly overhangs the posterior margin by an acute semicircular shelf edge. The ventral pseudointerarea is orthocline, short, gently inclined posteroventrally, without distinct flexure lines. The pseudointerarea is divided by a short, broad and shallow pedicle groove, which continues on the internal posterior slope of the visceral area as an anteriorly gently-expanding groove. The anterior edge of the propareas is not undercut, forming a high, undivided steep slope. The surfaces of the propareas and the pedicle groove are striated parallel with the shell margin. The visceral area is weakly impressed, rhomboidal, extending $45 \%$ of the valve length. The scars of the umbonal muscles are deeply impressed posteriorly, expanding and shallowing anteriorly, divided from each other by a short ridge. Another pair of scars is present on the posterolateral slopes, corresponding to the transmedian and anterior lateral muscles. Pallial markings are not distinctly impressed.

Ornament consists of weak growth fila distinct posterolaterally, which weaken anteriorly and axially. The first-formed and brephic shells are almost circular, $550 \mu \mathrm{m}$ wide and $600 \mu \mathrm{m}$ long, with a smooth centre and concentric wavy lines along the periphery. The surface lacks pitted microornament (Fig. 3Q). Microornament of the early mature shell consists of small, deep, hemispherical pits arranged in radial rows. Diameter of pits rapidly increases from $c a 1 \mu \mathrm{m}$ to $3 \mu \mathrm{m}$ (Fig. 3Q). This regular pitting of $c a$ $3 \mu \mathrm{m}$ sized pits is uniform over the entire surface of the mature shell, although it is less distinct anteriorly and axially than posterolaterally, probably resulting from abrasion of the shell surface.

Remarks. - The new species is assigned to Kosagitella because of the thick-walled shell, small shell size, robust ventral pseudointerarea with shallow and short pedicle groove,

Figure 3. Kosagitella pulsatilla sp. nov. $\bullet$ A-D, N- holotype, dorsal valve, detail of the apex, microornament on posterolateral part of the valve, side view, and the anterior part of the valve, PCZCU 1716. • E, F, P - ventral valve exterior, side view, and detail of the mature shell with microornament, PCZCU 1717. • G, Q - dorsal valve exterior, and contact of juvenile shell with early mature shell showing hemispherical pits of the mature shell, PCZCU 1725 . $\bullet-\mathrm{J}, \mathrm{O}-$ dorsal valve interior, detail of the pseudointerarea, oblique view with distinct anterior border of the pseudointerarea, and detail of posterior shell wall showing striation of the median groove, PCZCU 1718 . $\bullet \mathrm{K}$ - ventral valve interior, PCZCU 1720 . $\bullet$ L, M - ventral valve interior showing posterior edge of the first-formed shell, and oblique view, PCZCU 1719. All specimens come from the Acanthopyge Limestone (middle part), Preisler Quarry, Koněprusy. Length of bar in $\mu \mathrm{m}$. 
Michal Mergl • Lingulate brachiopods from the Acanthopyge Limestone (Eifelian)

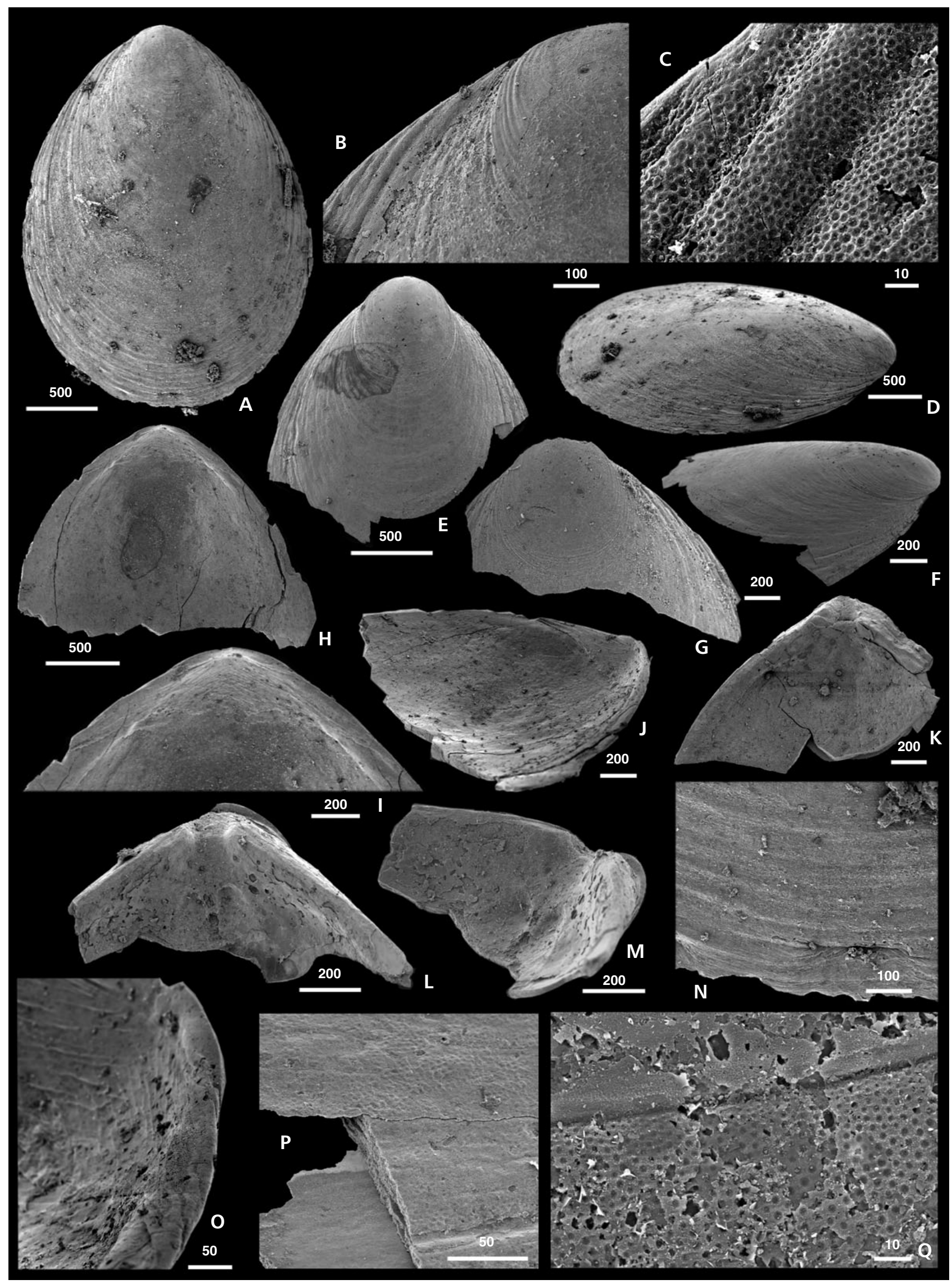


and low dorsal pseudointerarea. The new species was confused by Mergl (2001) with K. lingua (Barrande, 1879), the holotype of which is missing; the lectotype came from the Pragian Dvorce-Prokop Limestone. The different mode of preservation of the lectotype obscured many morphological details necessary for their comparison in that it shows a much elongated, elliptical outline, with maximum width at about midlength, and is much smaller and might represent a juvenile specimen.

Small linguloids from the Suchomasty Limestone (Emsian) (Mergl 2001; pl. 3, figs 16, 18.) probably do not belong to $K$. pulsatilla although they are of a similar size and show the same gross morphology. They differ in their broader shell outline with a more rounded posterior margin. They likely belong to another closely related species, a probable evolutionary forerunner of $K$. pulsatilla.

The type species $K$. clara Mergl, 2001 from the Kopanina Formation (Ludlow, Ludfordian) differs from the new species in its more elongate outline, larger size, and less distinct impression of the umbonal muscle scars. K. pinguis Mergl, 2001 from the Lower Devonian (Lochkovian) Kotýs Limestone differs in its more posteriorly-extended ventral pseudointerarea, which forms a very pointed ventral beak, and in its larger shell size.

The pitting of the mature shell is unknown in shells of stratigraphically older species, but similar hemispherical pits are known on the periphery of the dorsal pseudointerarea and the rounded posterior edge of the valve of K. pinguis (see Mergl 2001; pl. 4, fig. 15).

Occurrence. - Choteč Formation, Acanthopyge Limestone; Koněprusy, Preisler Quarry and a small quarry near road (abundant in samples AC1-AC3).

\section{Subfamily Glossellinae Cooper, 1956}

\section{Genus Microbolus gen. nov.}

Type species. - Microbolus micromorphus gen. et sp. nov.; Acanthopyge Limestone, Eifelian, Devonian; Barrandian, Czech Republic.

Diagnosis. - Micromorphic, relatively thick-shelled glosselline; shell with small ventral pseudointerarea, deep and prominent pedicle groove elongated into long deep furrow bounded by ridges (a pad below imprints of pedicle nerves) on the visceral area; dorsal pseudointerarea absent; muscle scars deeply impressed; internal surface with distinct epithelial cell moulds; exterior with irregular growth lines, pitted microornament absent; larval shell smooth.

Remarks. - Very small size distinguishes Microbolus from other obolids and similarly shaped micromorphic zhanatellids. The similarly micromorphic Tropidoglossa Rowell, 1966, and Pidiobolus Mergl, 1995 of the family Zhanatellidae Koneva, 1986 differ in having more finely pitted external microornament, a different ventral pseudointerarea with a broad propareas, and larval shells with elongate tubercles, which are absent in the new genus. Absence of the dorsal pseudointerarea justifies assigning the new genus to the subfamily Glossellinae Cooper, 1956 and this is supported also by the lack of a pitted microornament. Microbolus is unique among glossellines in its broadly triangular outline and minute size. The origin of the genus is probably paedomorphic. The thick-walled shell and deep muscle impressions indicate that specimens are adults and do not represent juvenile individuals of any larger glosselline species.

Species assigned. - Only the type species.

\section{Microbolus micromorphus sp. nov.}

Figures 4, 5

Diagnosis. - As for genus.

Holotype. - Ventral valve, PCZCU 1730 (Fig. 4A, F, G).

Paratype. - Dorsal valve, PCZCU 1731 (Fig. 4B, E, I).

Type horizon. - Eifelian, Acanthopyge Limestone, Polygnathus costatus costatus Zone.

Type locality. - Preisler Quarry near road Bykoš - Koněprusy, Koněprusy, central Bohemia, Czech Republic.

Name. $-\operatorname{Micros}($ Greek $)=$ small, and morphe $($ Greek $)=$ shape, after the diminutive size of the shell.

Material. - 20 specimens.

Figure 4. Microbolus minimus sp. nov. • A, F, G - ventral valve interior, oblique view, and anterior view showing deep muscle impressions and the pedicle groove, PCZCU 1730. • B, E, I - dorsal valve interior, oblique view, and anterior view showing deep muscle impressions, PCZCU 1731. - $\mathrm{C}, \mathrm{H}$ - dorsal valve exterior, and oblique view, PCZCU 1732. • D - ventral valve interior in oblique view, PCZCU 1736 . $\mathrm{J}-\mathrm{dorsal}$ valve with the first-formed shell, PCZCU 1734. • K - dorsal valve interior in oblique view, PCZCU 1733. • L - dorsal valve posterior margin with overhanging first-formed shell and the pseudointerarea, PCZCU 1735. M - microornament on posterolateral shell, PCZCU 1738. • N - microornament on anteromedian shell, PCZCU 1740. All specimens come from the Acanthopyge Limestone (middle part), Preisler Quarry, Koněprusy. Length of bar in $\mu$ m. 
Michal Mergl • Lingulate brachiopods from the Acanthopyge Limestone (Eifelian)

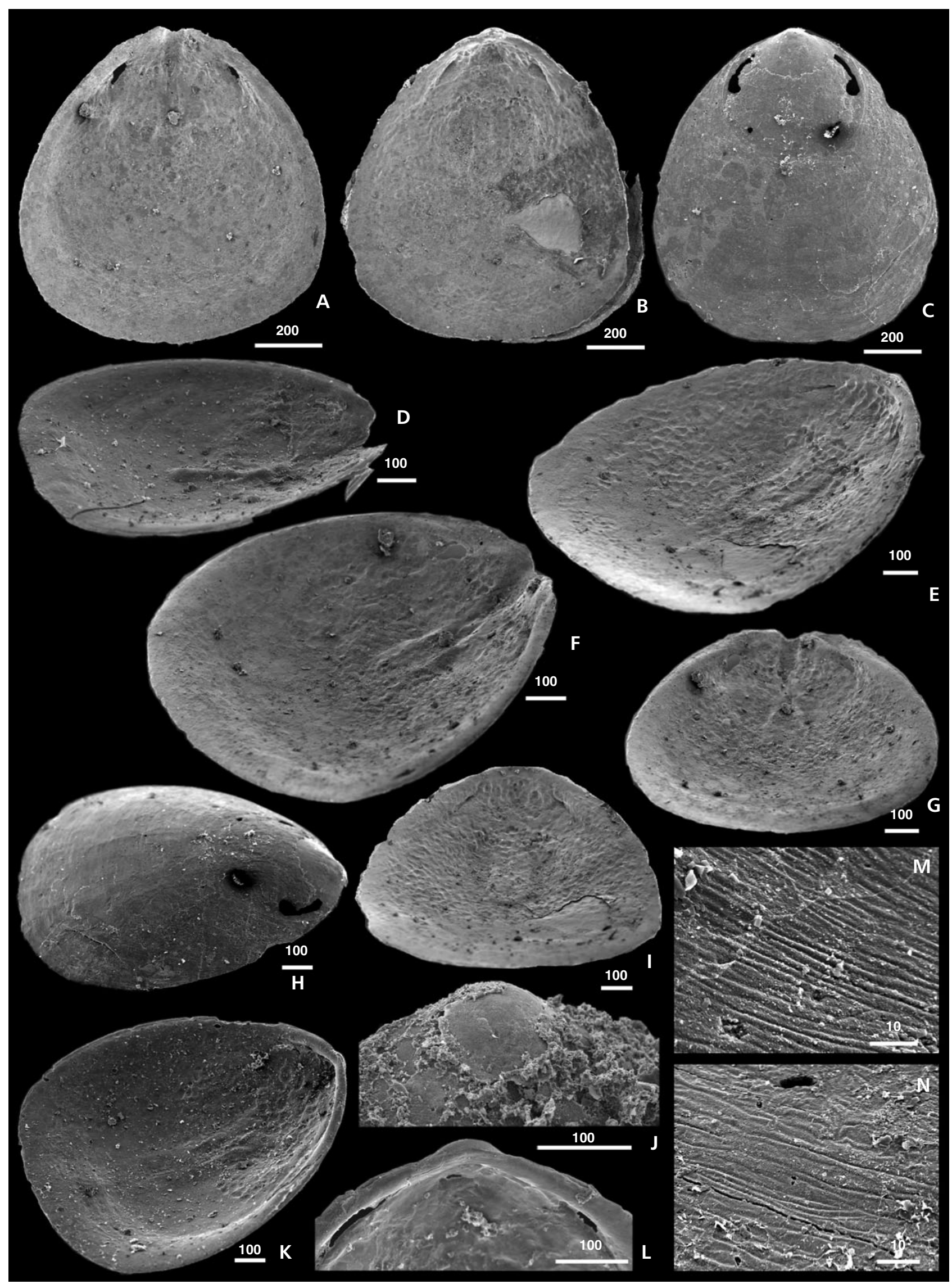




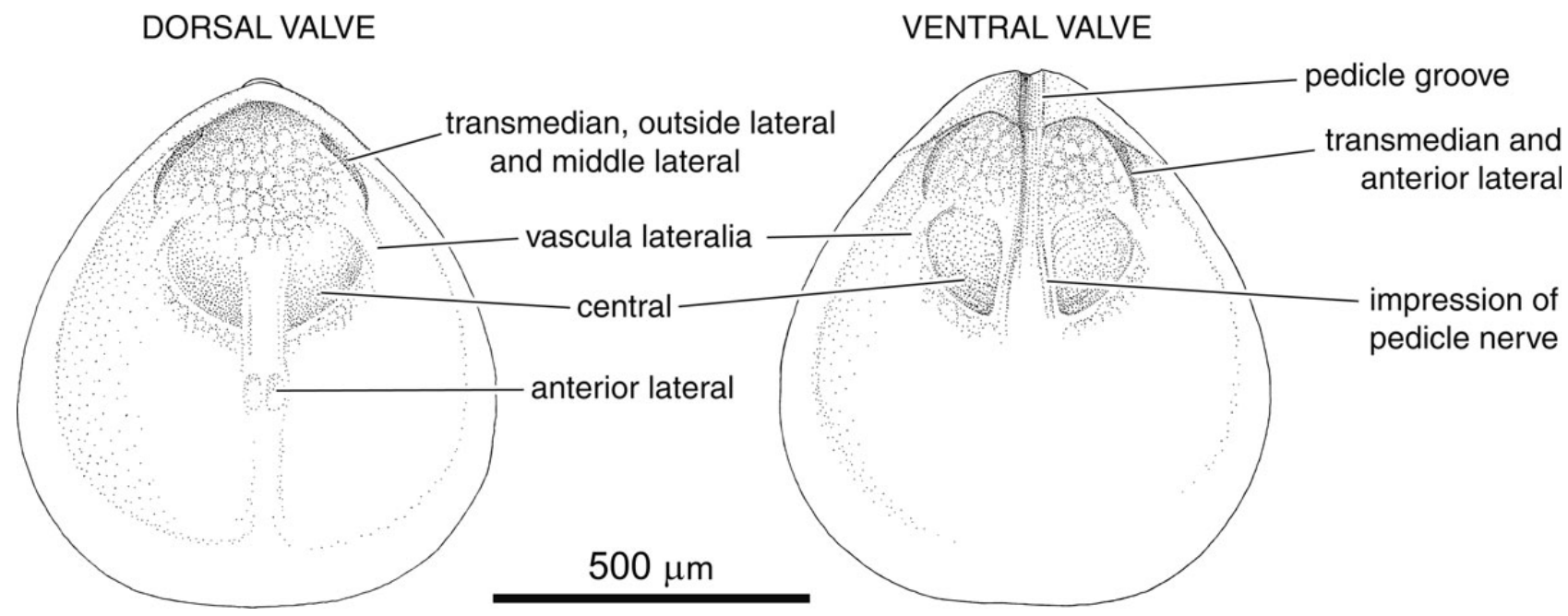

Figure 5. Microbolus minimus sp. nov. Schematic illustration of interior with muscle scars and mantle canal system.

Description. - The shell is biconvex, subtriangular, widest at the anterior third, fairly thick walled relative to shell size, $850 \mu \mathrm{m}$ wide in the largest specimens. The dorsal valve is gently convex, as long as wide, with a rounded posterior margin over which the edge of the larval shell slightly overlaps. Lateral and anterior margins are evenly rounded; only the axial part of the anterior margin is less rounded. The valve is moderately convex, with the maximum height in the midlength. A distinct dorsal pseudointerarea is absent being restricted to the thickened edge of the posterior margin and lacking a median groove and striated propareas. The visceral area is ill-defined being posterolaterally bounded by the deeply impressed, narrowly triangular undivided scars of the transmedian, outside and middle lateral muscles. The surface of these scars is steeply sloping axially. The central muscle scars are deeply impressed, elongate oval in outline, with subparallel inner margins, situated posterior to the valve midlength. The anterior projection is short, with anterior much anteriorly-situated and poorly-impressed lateral muscle scars. Pallial markings are not preserved.

The ventral valve has the same outline and convexity as the dorsal valve. The pedicle groove is deep, broad and short, anteriorly continuing in a shallow groove on the visceral area and reaching one-third of the valve length. This groove is laterally bounded by elevated subparallel ridges, which represent pads formed below the imprints of the pedicle nerves. The ventral pseudointerarea is small, with poorly-defined inner propareas steeply sloping toward the pedicle groove and the gently-sloping, short, broadly-triangular outer pseudointerarea. In all specimens observed, the posterior margin is broken off, indicating that the posterior shell edge was very thin and fragile. Umbonal muscle scars are weakly defined, but transmedian and anterior lateral muscle scars are deeply impressed by narrowly-triangular, oblique scars. Only a thin shell wall remains below the scars. This is evident from small perforations of the shell wall in the majority of ventral and dorsal valves preserved (Fig. 4A, C). A pair of undivided muscle scars (corresponding to central, middle and outside lateral muscles) is preserved in the posterior third of the valve. The inner surface of the visceral area is covered by circular, subpentagonal and hexagonal equidimensional pits of fairly uniform size ( 23 to $30 \mu \mathrm{m}$ ). These epithelial cell moulds are absent only on a flattened, smooth brim along the periphery of each valve (Fig. 4G, K).

The shell exterior is smooth except for very fine, irregular, interrupted and somewhat wrinkled rheomorphic growth lines and grooves, numbering five to six per $10 \mu \mathrm{m}$. A pitted microornament is absent.

Occurrence. - Choteč Formation, Acanthopyge Limestone; Koněprusy, Preisler Quarry and small quarry near road (abundant in samples AC1-AC3), central Bohemia.

Superfamily Discinoidea Gray, 1840

Family Discinidae Gray, 1840

\section{Genus Acrosaccus Willard, 1928}

Type species. - Acrosaccus schuleri Willard, 1928; Rich Valley Formation, Caradoc, Ordovician; Virginia, USA.

\section{Acrosaccus sp.}

Figure 6A-J

Material. - One complete dorsal valve, several shell fragments. 
Description. - The shell is $3.5 \mathrm{~mm}$ wide, subcircular, $103 \%$ as long as wide, low-conical with straight slopes having a tendency to be concave along the shell periphery. The apex is situated posterior to the midlength. The valve is thickwalled, progressively thickening during growth, showing breakage from injury on the left side. The first-formed shell is transversally oval, convex, $c a 150 \mu \mathrm{m}$ wide. The brephic shell is almost smooth, covered by weak growth lines. The first prominent interrupted concentric rugella appears $\mathrm{ca}$ $400 \mu \mathrm{m}$ anterior to the apex. Other rugellae are higher, more and more prominent anteriorly, forming a high lamellose ornament. The crests of the rugellae are rounded, slightly thickened compared with the bases of the rugellae. The interspaces are broad in the juvenile shell with a shorter and less regular span toward the shell periphery. The interspaces have a rounded bottom, without distinct growth lines.

The microornament consists of oval, poorly-ordered pits on the surface of the first-formed shell (Fig. 6E, F). These pits are shallow, ca $2 \mu \mathrm{m}$ long, mostly concave but ones with a convex surface and deeper imprinted periphery are also seen. The brephic shell near the contact with the first-formed shell shows smaller, $c a 1 \mu \mathrm{m}$ sized circular pits arranged in discrete radial rows (Fig. 6H). The rows become less distinct distally (Fig. 6I), where the microornament changes to chaotically and more densely-spaced uniformly-sized pits (Fig. 6G, J). The mature shell is densely covered with circular, $c a 1 \mu \mathrm{m}$ large, uniformly-sized pits without distinct arrangement.

Remarks. - The specimen is not formally described as a new species, but differs from all previously-reported species from the Prague Basin. Among these species the most similar is Acrosaccus bubovicensis (Mergl, 2001) of Wenlock age.

The microornament of the larval shell consists of small slightly concave and convex elliptical pits that evidently represent imprints of the siliceous tablets present in extant discinoids (Williams et al. 1998, 2001). The same ornament is known in other species assigned to Acrosaccus (Holmer 1987, Holmer \& Popov 2000). Similar imprints have been reported in the Silurian Opatrilkiella Mergl, 2001 and Devonian Schizotreta Kutorga, 1848. The pits of the first-formed shell of Acrosaccus sp. are larger, shallow and clearly differ from smaller, hemispherical vesicular pits covering the mature shell. The rows of smaller hemispherical vesicular pits (Fig. 6H) are present already on the lamellar ring of the Acrosaccus shell (see Williams et al. 2001, Williams 2003). Evidence of distinct imprints of tablets in the first-formed shell indicates that this type of pitting already appeared, if not earlier, in the Silurian and early Devonian discinoids. Consequently, the tablet cover of the larval shell cannot be an apomorphy of extant discinoids as suggested by Williams et al. (1998).
Occurrence. - Choteč Formation, Acanthopyge Limestone; Koněprusy, Preisler Quarry and small quarry near road (rare in samples AC1-AC3), central Bohemia.

\section{Genus Chynithele Havlíček, 1996}

Type species. - Chynithele ventricona Havlíček 1996; Zlíchov Formation, Emsian, Lower Devonian; Barrandian, Czech Republic.

\section{Chynithele amoena sp. nov.} Figure 7

Holotype. - Dorsal valve, PCZCU 1722 (Fig. 7A, D, F, J).

Paratype. - Ventral valve, PCZCU 1723 (Fig. 7E, G, H, K).

Type horizon. - Eifelian, Acanthopyge Limestone, Polygnathus costatus costatus Zone.

Type locality. - Preisler Quarry near road Bykoš - Koněprusy, Koněprusy, central Bohemia.

Name. - Amoenus $($ Latin $)=$ nice, pretty .

Material. - Three dorsal valve, two ventral valves, many fragments.

Diagnosis. - Chynithele shell with transversally-elliptical outline; dorsal valve deeply concave, with weakly-convex apical region; dorsal apex situated more posteriorly; weakly-curved posterior margin; ornament of high lamellose rugellae with characteristic T-profile in the dorsal valve; first rugella in dorsal valve appears abruptly.

Description. - The shell is concavo-convex, thick-shelled, $4 \mathrm{~mm}$ wide, $80 \%$ as long as wide. The dorsal valve is transversally elliptical, with evenly-rounded anterior and lateral margins. The posterior margin is distinctly less curved. The maximum width lies in the posterior two-fifths. The valve is moderately to deeply concave in lateral profile, with a flat apical region showing low elevation around the gently-convex brephic shell. The apex is situated in posterior $20 \%$ of the length. The ornament consists of fine concentric filae in the juvenile and early mature shell. The first coarse rugella appears $\mathrm{ca} 1 \mathrm{~mm}$ anteriorly from the apex and the next rugellae are regularly spaced on the mature shell. Apart from rare exceptions, the rugellae are continuous, being more densely crowded on the posterior slope, with regular span intervals. The rugellae are high, irregularly T-shaped in profile, with broad, strip-like crests, which are deeply excavated anteriorly and only obsolete posteriorly. 
The size of the rugellae does not change on the remaining parts of the mature shell. Interspaces are deep, with flat bottoms, with a weak rheomorphic ornament (Fig. 7C, I).

The first-formed dorsal shell is gently convex, broadly elliptical, ca $300 \mu \mathrm{m}$ wide, with weakly-defined margins. The pitting on its surface is not discernible. The dorsal valve interior is the same as the type species (Mergl 2001).

The ventral valve is asymmetrically conical, with a steep, gently-convex posterior slope and a moderate straight to gently-concave anterior slope. The apex is situated more posteriorly, covered by the weakly-defined first-formed shell. The pedicle track is short, shallow, occupying less than one-third of the posterior slope, gently widening posteriorly. The pedicle track shows distinct, broad, and weakly-striated lateral plates of a listrium and a low, gently-convex median plate. The first-formed shell extends by a short shelf above the early pedicle track. The pedicle opening is small and transversally triangular. The ornament of the ventral valve is less prominent than that of the dorsal valve. It consists of weakly-defined concentric growth filae, which become coarser with shell growth. High rugellae are always absent. The growth filae are somewhat irregular forming folds and drapes. This is clearly visible on repaired parts of the shell (Fig. 7E, G).

The microornament consists of fine, hemispherical pits (Fig. 7K). These are densely and regularly arranged in all surfaces, covering interspaces, crests, and slopes of the rugellae in the dorsal valve and entire folds and the filae of the ventral valve. The pits are uniform in size, $c a 2 \mu \mathrm{m}$, never arranged in discrete arrays. The pitting is absent on the surface of listrial plates.

Remarks. - The new species differs from the type species Chynithele ventricona Havlíček, 1996 from the older Chýnice Limestone (mid Emsian) by its less circular outline, clearly less curved posterior margin and deeper concave dorsal valve. Differences are seen also in the ornament of the dorsal valve. Newly-etched specimens of $C$. ventricona from the type locality (Bubovice, Čeřinka) show finer and more tightly-arranged concentric rugellae than those described here in the new species. The surface of the early mature shell of $C$. vetricona shows the gradually growing size of concentric rugellae, whereas the surface of the early mature shell in all studied dorsal valves of $C$. amoena sp. nov. are covered only with fine concentric filae; the first coarse rugella starts abruptly, $\mathrm{ca} 1 \mathrm{~mm}$ anteriorly from the apex. The microornament of both species is the same, consisting of uniformly-sized hemispherical pits over the entire surface. This microornament was first mentioned in $C$. sp. cf. C. ventricona from the Early Devonian of New South Wales by Valentine (2006), but unlike C. amoena, the Australian species shows rugellate ornament already on the early mature shell and its shell outline is subcircular.

Specimens from the Suchomasty Limestone (upper Emsian) referred to $C$. ventricona by Mergl (2001) probably belong to $C$. amoena. They have a transversally-elliptical outline although there is one specimen with a different, more circular outline (Mergl 2001, pl. 20, figs 14-77, 18). Clarity of their systematic position requires further investigation of the specimens from the Suchomasty and Chýnice limestones.

Occurrence. - Choteč Formation, Acanthopyge Limestone; Koněprusy, Preisler Quarry and small quarry near road (common in samples AC1-AC3).

\section{Genus Opatrilkiella Mergl, 2001}

Type species. - Opatrilkiella minuta Mergl, 2001; Požáry Formation, Př́idolí, Silurian; Barrandian, Czech Republic.

\section{Opatrilkiella kobyla sp. nov.}

Figures 8, 9

2001 Opatrilkiella (?) sp. B. - Mergl, p. 30, pl. 24, fig. 10.

Holotype. - Ventral valve, PCZCU 1729 (Fig. 8A, D).

Paratype. - Dorsal valve, PCZCU 1728 (Fig. 8G).

Type horizon. - Eifelian, Acanthopyge Limestone, Polygnathus costatus costatus Zone.

Type locality. - Preisler Quarry near road Bykoš - Koněprusy, Koněprusy, central Bohemia.

Name. - After Kobyla Hill near the type locality.

Material. - 20 valves, numerous fragments.

Diagnosis. - Opatrilkiella shell with ventral apex situated in anterior two-fifths; distinct irregular concentric orna-

Figure 6. Acrosaccus sp. • A-J - dorsal valve exterior, detail of the apex (B), damaged valve (C), detail of rugellae (D), the first-formed shell (E), pitting of the first-formed shell, note concave and convex pits (F), pitting of a slope of rugellae (G), pitting of the brephic shell (H), pitting of the early mature shell (I), and pitting of the mature shell (J), PCZCU 1715. Orbiculoidea sp. $\bullet \mathrm{K}-\mathrm{N}-$ dorsal valve (K), detail of the apex (L), ornament of the mature shell (M), and microorrnament of arrays of hemispherical pits (N), PCZCU 1714. Both specimens come from the Acanthopyge Limestone (middle part), Preisler Quarry, Koněprusy. Length of bar in $\mu \mathrm{m}$ or in $\mathrm{mm}$. 


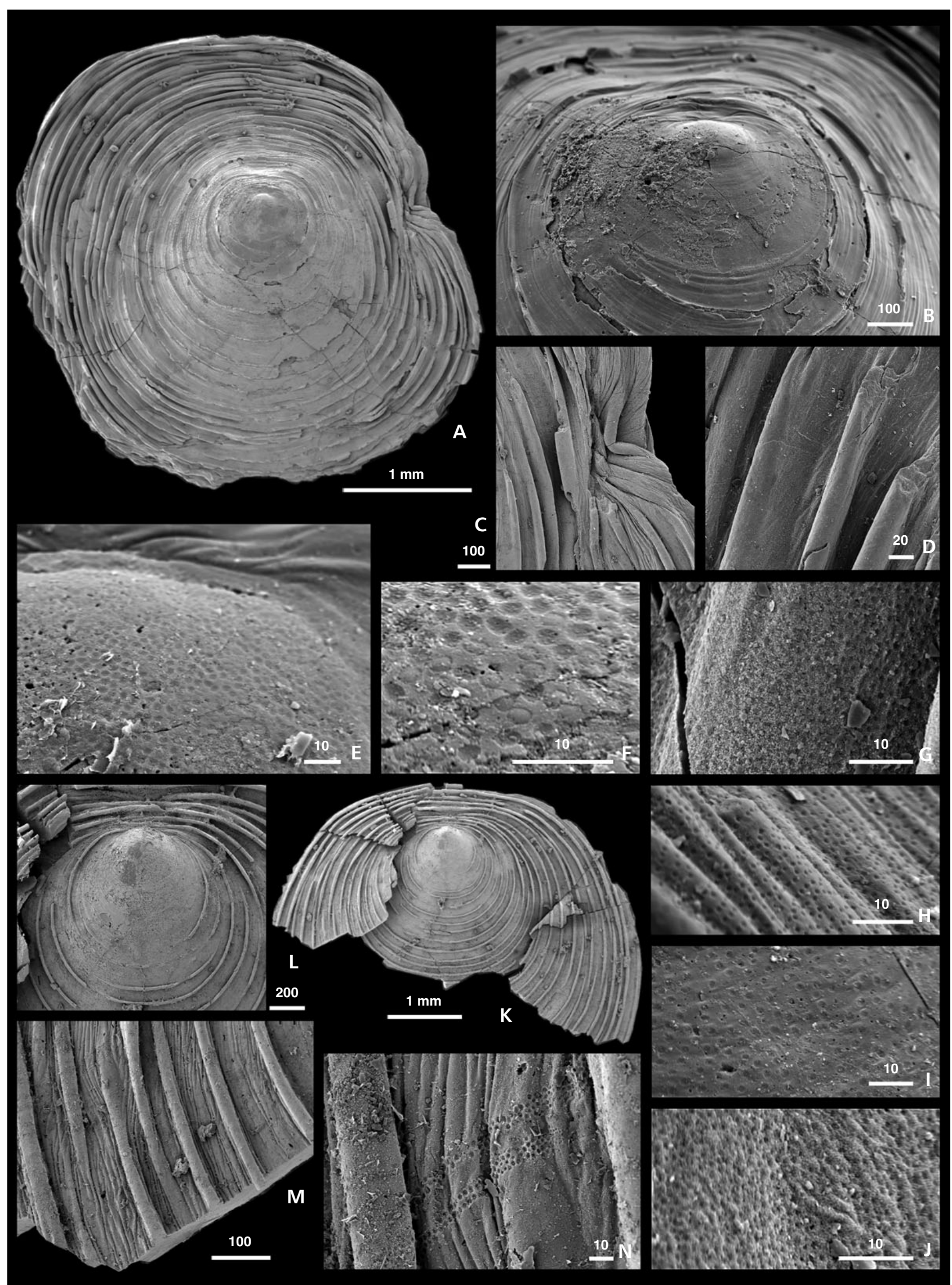


ment with superimposed prominent and numerous radial folds and drape-like concentric folds over majority of mature shell; pitting in mature shell absent.

Description. - The shell is ventribiconvex, thick-walled relative to the shell size. The size of the largest specimen does not exceed $1.7 \mathrm{~mm}$. Remarkably, the shell outline varies significantly ranging from subcircular to subtrapezoidal, in some specimens also almost parallel-sided, 103 to $132 \%$ as long as wide. The maximum width is located between shell midlength and the anterior one-third.

The dorsal valve has a submarginal apex and maximum height at the apex. The posterior margin is gently rounded, the anterior margin semicircular, with the posterolateral margins less curved. The anterior slope is gently convex, with an elevated first-formed shell. The posterior slope is steep, gently flattened to weakly concave in lateral profile. The dorsal interior shows a weakly-defined visceral area. Small and weakly-impressed muscle scars of the posterior oblique, posterior adductor and oblique internal muscles border a steep posterior slope on the visceral area. Anterior adductor scars are large, oblique, subrectangular, extending to one-third of the valve. A very faint median ridge is present at the bottom of the visceral area. A short and broad anterior projection is present, but it is devoid of distinct muscle imprints. The proximal part of the vascula lateralia projects in between the anterior adductor and oblique lateral muscle scars.

The ventral valve is slightly more convex than the dorsal valve, with a gently-convex anterior slope. The pedicle track is narrowly triangular, laterally bordered by an acute edge with abrupt flexure of the growth lines. The pedicle track is steeply sloping, with gently-concave lateral listrial plates, which are laterally- and medially-fused by a thin cover of the pedicle slit. The posterior edge of the pedicle track forms a shallow emargination at the posterior margin. The pedicle track internally forms a high ridge with a rounded crest. The visceral area is weakly defined, anterolaterally bordered by prominent, weakly-impressed oblique anterior adductor muscle scars. Other undivided muscle scars are located posterolaterally, separated from the anterior adductors by proximal parts of a weak, arcuate vascula lateralia. The internal periphery of both valves is slightly flattened, forming a low narrow brim laterally and anteriorly.

The first-formed shell is distinct in its smooth surface and convexity. Both ventral and dorsal first-formed shells have a subcircular outline, $120 \mu \mathrm{m}$ in width and both facing posteroventrally. The ventral shell is posteriorly extended into the acute edge overlapping over the pedicle track. The anterior boundary and sides of the first-formed shell are less clearly defined. Its surface is covered by a mosaic of shallow rhombic pits (Fig. 8L), which are probably imprints of the siliceous tablets known in other discinoid juvenile shells (Holmer 1989, Williams et al. 1998). The surface of the mature shell is covered by concentric, somewhat wavy growth fila of uniform size. Radially-arranged, wavy rheomorphic folds are superimposed onto concentric fila. The density of radial and concentric to oblique drape-like folds differs considerably among the specimens (see Fig. 8B, C) and also in different parts of the same shells. Radial folds are present also on the posterior slope of the dorsal valve (Fig. 8J, N, O). Pitting of the mature shell has not been observed in any specimens.

Remarks. - The new species differs from the type species O. minuta Mergl, 2001 in its less rounded posterior dorsal valve margin and by a more anteriorly situated dorsal and ventral apices. However, the main difference concerns the microornament, which consists of numerous radial and subconcentric rheomorphic folds in O. kobyla whereas this type of ornament is absent in $O$. minuta. Instead of this microornament, the shell of $O$. minuta bears radial arrays of fine pits separated by smoother, wide interspaces. Rheomorhic radial folding is very weak in O. minuta (see Mergl 2001; pl. 24, fig. 5). The shell assigned to Opatrilkiella(?) sp. B from the Choteč Limestone belongs to the same species, showing the same outline, convexity, and microornament as the specimens from the Acanthopyge Limestone. The species Opatrilkiella sp. A figured by Mergl (2001) belongs to another formally undescribed species, which is unknown in the Acanthopyge Limestone.

Shells of Opatrilkiella are morphologically similar and can be confused with juvenile shells of Schizotreta. In all samples of the Acanthopyge Limestone the specimens of Opatrilkiella kobyla reach a final size of about $1.5 \mathrm{~mm}$ long. It is worthwhile to note that the posterior closure of the pedicle track has not been observed. The ventral valve of $O$. kobyla figured here (Fig. 8A, D) shows a remarkably thick and anteriorly-broken shell together with a thickened but otherwise unbroken posterior edge of the pedicle track. This indicates that the pedicle protruded between the valves at the posterior margin through a transverse, narrowly-triangular pedicle slit. This is supported by the presence of densely-spaced, curved folds on the posterior slope of the dorsal valve (Fig. 8F, K), which indicates a stressed circumstance along the generative zone of the posterior

Figure 7. Chynithele amoena sp. nov. $\bullet \mathrm{A}, \mathrm{D}, \mathrm{F}, \mathrm{J}-$ dorsal valve exterior, lateral view, detail of ornament with T-shaped profile of rugellae, and detail of rugellae, PCZCU 1722. • B, C, I - incomplete dorsal valve exterior, detail of rugellae, and detail of microornament and rheomorhic growth lines, PCZCU 1724. E E, G, H, K - incomplete ventral valve, detail of shell injury, the shell in oblique view, and detail of microornament, PCZCU 1723 . All specimens come from the Acanthopyge Limestone (middle part), Preisler Quarry, Koněprusy. Length of bar in $\mu \mathrm{m}$. 


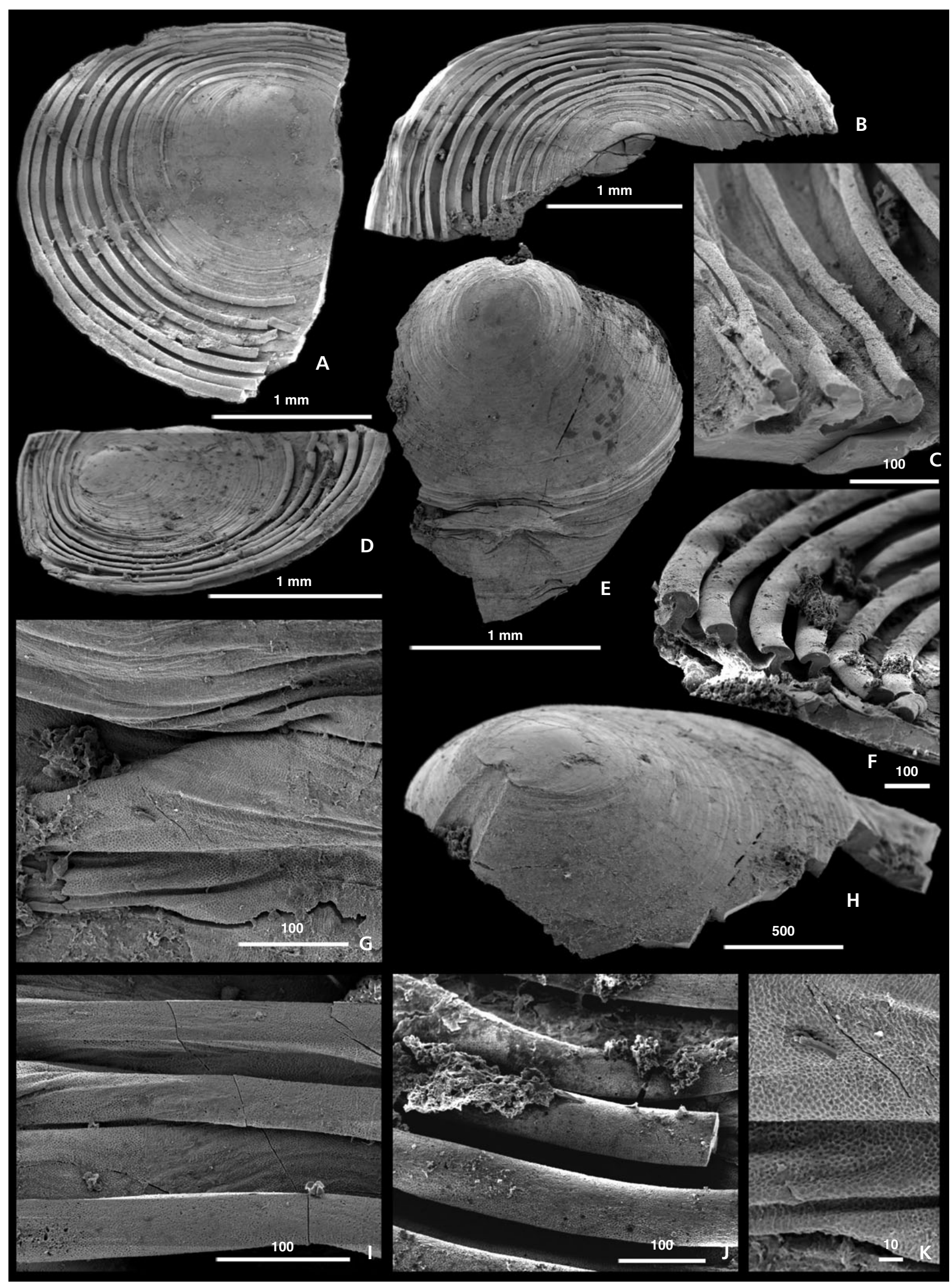


margin. Musculature and the mantle canal system is the same as described by Holmer \& Popov (2000) in Schizotreta and their interpretation is illustrated here (Fig. 9).

The genus Opatrilkiella was reassigned from the Trematidae Schuchert, 1893 to the Discinidae Gray, 1840 by Williams (2003) based on the absence of pits on the juvenile shell of other trematids.

Occurrence. - Choteč Formation, Choteč Limestone (lower part, bed 13); Praha-Holyně, Prastav Quarry (rare). Choteč Formation, Acanthopyge Limestone; Koněprusy, Preisler and Jirásek quarries, and small quarry near road (abundant in samples $\mathrm{AC} 1-\mathrm{AC} 3$, rare in $\mathrm{AC} 4)$, central Bohemia.

\section{Genus Orbiculoidea d'Orbigny, 1847}

Type species. - Orbicula forbesii Davidson, 1848; Much Wenlock Limestone, Wenlock, Silurian; West Midlands, England.

\section{Orbiculoidea sp.}

Figure 6K-N

Material. - One dorsal valve, several fragments of dorsal valves, one fragment of the ventral valve.

Description. - The thin-shelled shell is elongate elliptical, asymmetrically low conical, with the apex situated posteriorly. The shell margins are evenly curved except at the posterior margin, which is slightly depressed. The maximum width lies slightly anterior of the midlength. The apex is slightly pointed, with a circular, convex first-formed shell. The anterior slope is gently convex, the posterior slope is shorter, much steeper, and straight.

Ornament consists of concentric rugellae of uniform size. The first-formed rugella appeared $600 \mu \mathrm{m}$ anterior from the apex. Other rugellae are evenly spaced over the shell surface, being more densely crowded in the posterior slope than anteriorly and laterally. Some concentric rugellae are not entire, being interrupted on the flanks, with new rugellae intercalated and the disappearance of another near the same place. The new rugellae rapidly attain the usual size (Fig. 6K, M) and, similarly, already existing rugellae rapidly disappear. All rugellae are low, evenly wide ( $c a 25$ to
$30 \mu \mathrm{m})$, having rounded crests, with almost the same height (ca $20 \mu \mathrm{m}$ ) as width. Rugellae are evenly thick or have gently-thinner bases than the crests. Interspaces are wider ( $c$ a 30 to $100 \mu \mathrm{m}$ ) than rugellae, having a flat bottom and the surface is covered by low uniformly-sized rheomorphic growth lines (Fig. 6M). There are usually four to ten lines in the interspaces on the anterior slope.

Microornament consists of narrow arrays of vesicular pits ( $c a 3 \mu \mathrm{m}$ in size) separated from each another by broad interspaces with rheomorphic structure that is covered by much smaller (less than $1 \mu \mathrm{m}$ ) vesicular pits (Fig. 6N).

The ventral valve is poorly preserved and not illustrated here. It is flat, conical or planar, with a surface covered by more distantly-spaced rugellae ornament and large, distinct, gently-inclined lateral listrial plates.

Remarks. - The collected shells and fragments do not allow formal description of a new taxon and the affinity of the species is somewhat unclear. The ornament of fine, distant and clearly-defined rugellae, low conical dorsal valve, moderate thick shell, circular outline of the brephic shell with smooth first-formed shell, and the microornament of very fine vesicular pits and arrays of larger vesicular pits on the mature shell justify its attribution to Orbiculoidea d'Orbigny, 1847. The first-formed shell does not show any pitting.

Occurrence. - Choteč Formation, Acanthopyge Limestone; Koněprusy, Preisler Quarry (moderately abundant), central Bohemia.

Order Acrotretida Kuhn, 1949

Superfamily Acrotretoidea Schuchert, 1893

Family Biernatidae Holmer, 1989

\section{Genus Opsiconidion Ludvigsen, 1974}

Type species. - Opsiconidion arcticon Ludvigsen, 1974; Emsian, Devonian; Yukon, Canada.

\section{Opsiconidion decessus Mergl, 2001}

Figure 10

2001 Opsiconidion decessus sp. nov.; Mergl, p. 34, pl. 31, figs 4-16.

Figure 8. Opatrilkiella kobyla sp. nov. • A, D - ventral valve exterior, oblique view, note thick shell, PCZCU 1729 . • B, I, J, L-O - ventral valve exterior, note circular shell outline (B), oblique view (I), ornament at the anterior margin (J), the first-formed shell with rows of pits (L), rheomorhic microornament of the mature shell $(\mathrm{M}, \mathrm{N})$, and detail of microornament $(\mathrm{O}), \mathrm{PCZCU} 1726 . \bullet \mathrm{C}, \mathrm{E}$ - ventral valve exterior, note parallel-sided outline, and oblique view, PCZCU 1727. • G - dorsal valve exterior, PCZCU 1728 . F, K - incomplete dorsal valve exterior, and detail of the posterior slope, PCZCU 1737. • H - ventral valve exterior in oblique view, PCZCU 1738. All specimens come from the Acanthopyge Limestone (middle part), Preisler Quarry, Koněprusy. Length of bar in $\mu \mathrm{m}$. 
Michal Mergl • Lingulate brachiopods from the Acanthopyge Limestone (Eifelian)

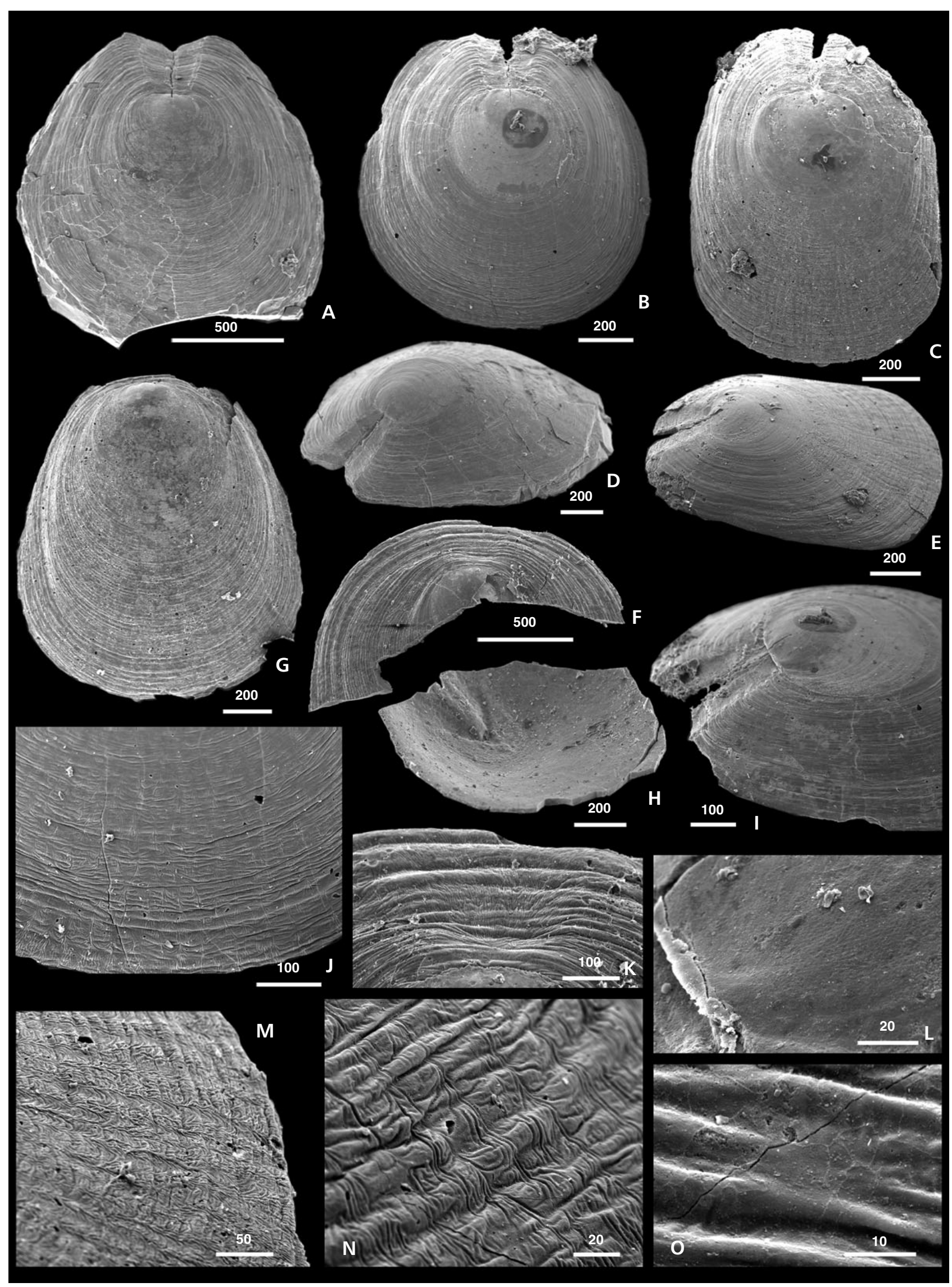




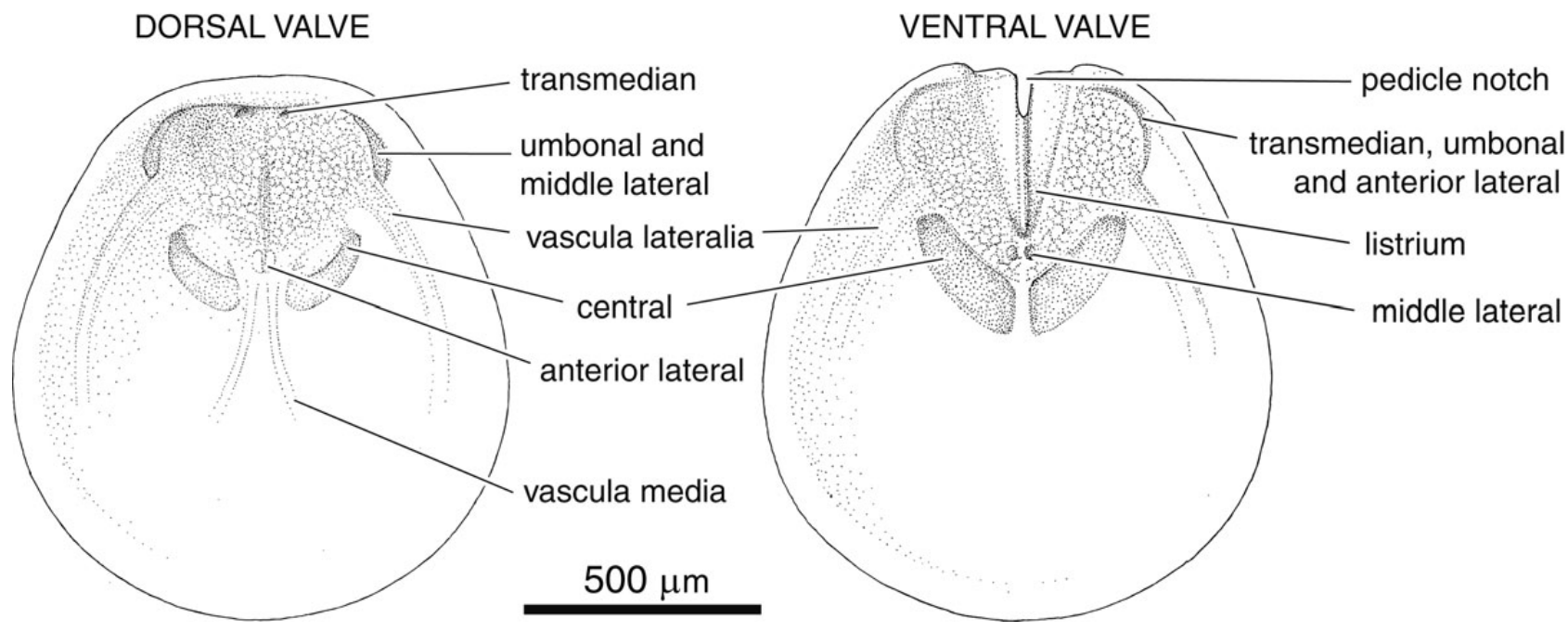

Figure 9. Opatrilkiella kobyla sp. nov. Schematic illustration of the interior with muscle scars and mantle canal system, based on that of Holmer \& Popov (2000) for Schizotreta.

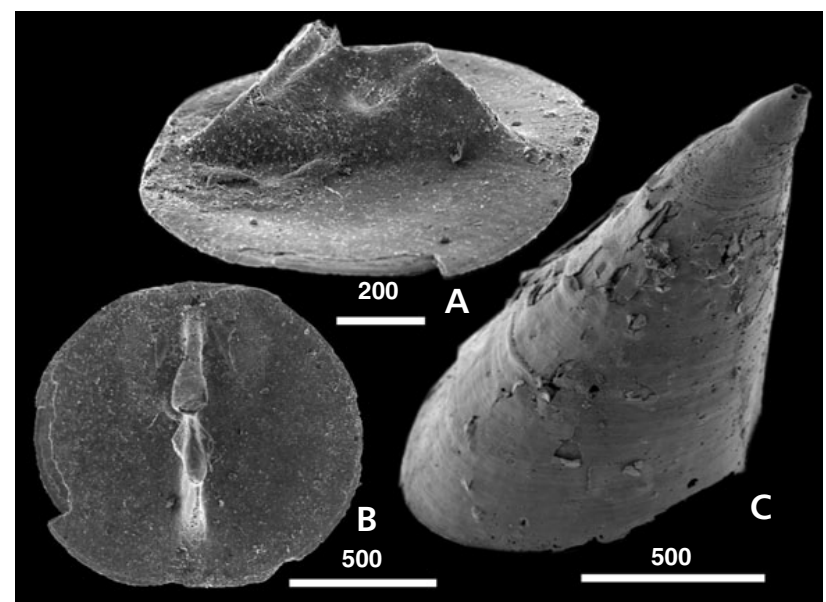

Figure 10. Opsiconidion decessus Mergl, 2001. A, B - dorsal valve interior, PCZCU 1736. • C - ventral valve exterior, PCZCU 1721. Both specimens come from the Acanthopyge Limestone (middle part), Preisler Quarry, Koněprusy. Length of bar in $\mu \mathrm{m}$.

Material. - One ventral and one dorsal valve.

Description. - See Mergl (2001).

Remarks. - The species has been known exclusively from the basal layers of the Choteč Limestone in the Prastav Quarry at Praha-Holyně (Mergl 2001). The newly collected shells show the characteristic features of the species: a straight, tall, acutely conical ventral valve with a narrow catacline pseudointerarea and a dorsal valve with dorsal median septum having an anteriorly-expanded surmounting plate and long lower rod. Compared with other lingulate brachiopods of the Acanthopyge Limestone, this species is rare and indicates that the biernatide Opsiconidion preferred a calmer, deeper environment.
Occurrence. - Choteč Formation, Choteč limestone (basal layers); Praha-Holyně, Prastav Quarry (abundant). Choteč Formation, Acanthopyge Limestone; Koněprusy, Preisler Quarry (rare in samples AC1 and AC2), central Bohemia.

\section{Conclusions}

The composition of the lingulate brachiopod fauna of the Acanthopyge Limestone indicates evolutionary continuity and general uniformity of the fauna from Wenlock time to the mid-Devonian in the Prague Basin. There are characteristic taxa of the shallow-water biofacies, with moderately-sized Acrosaccus, Orbiculoidea, Chynithele and Kosagitella. Genera Chynithele and Opatrilkiella manifest the tight evolutionary affinity of the lingulates of the Acanthopyge Limestone (Eifelian; Choteč Formation) with those of the Chýnice Limestone (mid-Emsian, Zlíchov Formation). The biernatids are represented by rare Opsiconidion decessus in the Acanthopyge Limestone. The biernatid Havlicekion, a characteristic element of the Wenlock to mid-Emsian shallow biofacies of the Prague Basin (Mergl 2001) is already absent in the Eifelian Limestone.

\section{Acknowledgements}

The author is greatly indebted to J. Hladil (Academy of Sciences of the Czech Republic, Prague) for important data concerning the Acanthopyge Limestone and to J. Nebesářová, J. Vaněček, and T. Bílý (Academy of Science of the Czech Republic, České Budějovice) for help with SEM study. This study was supported by a grant of the Grant Agency of the Czech Republic GAČR 205/07/0466: Origin and evolution of the discinoid brachiopods in the Palaeozoic. 


\section{References}

BARRANDE, J. 1846. Notice préliminaire sur le Système Silurien et les Trilobites de Bohême. 97 pp. Hirschfeld, Leipzig.

BARRANDE, J. 1879. Systême silurien du Centre de la Bohême. $I^{\text {re }}$ partie: Recherches Paléontologiques. Volume 5. Classe des Mollusques. Ordre des Brachiopodes. 226 pp. Privately published, Prague \& Paris.

CHLUPÁČ, I. 1957. Facial development and biostratigraphy of the Lower Devonian of Central Bohemia. Sborník Ústředního ústavu geologického, Oddíl geologický 23, 369-485.

CHLUPÁČ, I. 1959. Facial development and biostratigraphy of Daleje Sahles and Hlubočepy Limestones (Eifelian) in the Devonian of Central Bohemia. Sborník Ústředního ústavu geologického, Oddíl geologický 24, 446-511.

CHLUPÁČ, I. 1977. The phacopid trilobites of the Silurian and Devonian of Czechoslovakia. Rozpravy Ústředního ústavu geologického 23, 1-172.

CHLUPÁČ, I. 1983. Trilobite assemblages in the Devonian of the Barrandian area and their relations to palaeoenvironments. Geologica et Palaentologica 17, 43-73.

CHLUPÁČ, I. 1998. Devonian, 101-133. In CHLUPÁČ, I., HAVLíČEK, V., KŘíž, J., KuKAL, Z. \& S̆TORCH, P. Palaeozoic of the Barrandian (Cambrian to Devonian). Czech Geological Survey, Prague.

ChluPÁČ, I., HLADIL, J. \& LuKEŠ, P. 1986. Barrandian - Moravian Karst 1986. Excursion - Guidebook. Subcomission on Devonian Stratigraphy of the International Commission on Stratigraphy. 62 pp. Ústřední ústav geologický, Praha.

COOPER, G.A. 1956. Chazyan and related brachiopods. Smithsonian Miscellaneous Collection 127, 1-1245.

COOPER, G.A. 1960. Correction of brachiopod names. Journal of Paleontology 34, 601.

Cusack, M., Williams, A. \& Buckman, J.O. 1999. Chemicostructural evolution of linguloid brachiopod shells. Palaeontology 42(5), 799-840. DOI 10.1111/1475-4983.00098

DAVIDSON, T. 1848. Mémoire sur les brachiopodes du Système silurien supérieur de l'Angleterre. Bulletin de la Société géologique de France (série 2) 5, 309-338, 370-374.

GALLE, A. \& HLADIL, J. (eds) 1991. Lower Paleozoic corals of Bohemia and Moravia. VI. International Symposium of Fossil Cnidaria including Archaeocyatha and Porifera, Münster, Germany, Excursion Guidebook B3. 83 pp. Westfälischen Wilhelms Universität, Münster.

GRAY, J.E. 1840. Synopsis of the contents of the British Museum, $42^{\text {th }}$ edition. 370 pp. British Museum, London.

HAVLíČEK, V. 1982. Lingulacea, Paterinacea, and Siphonotretacea (Brachiopoda) in the Lower Ordovician sequence of Bohemia. Sborník geologických věd, Paleontologie 25, 9-82.

HAVLíčEK, V. \& KuKAL, Z. 1990. Sedimentology, benthic communities, and brachiopods in the Suchomasty (Dalejan) and Acanthopyge (Eifelian) Limestones of the Koněprusy area (Czechoslovakia). Sborník geologických věd, Paleontologie 31, 105-205.

HAVLÍČEK, V. \& VANĚK, J. 1996. Brachiopods and trilobites in the Chýnice Limestone (Emsian) at Bubovice (Čeřinka hillside; Prague Basin). Palaeontologica Bohemiae 2, 1-16.

HAWLE, I. \& CORDA, A.J.C. 1847. Prodrom einer Monographie der böhmischen Trilobiten. 176 pp. J.G. Calve, Prague.

HLADIL, J. 1993. Tabulatomorphs and stromatoporoids below and above the upper boundary of the Acanthopyge Limestone (Eifelian/Givetian transition interval, Central Bohemia) V̌̌stník Českého geologického ústavu 68(2), 27-42.

HLADIL, J., BEROUŠEK, P. \& LUKEŠ, P. 1992. Temné vápencové vrstvy při stropu akantopygových vápenců u Koněprus - otomari-Kačák event. Zprávy o geologických výzkumech v roce 1991, 53-55.

HOLMER, L.E. 1987. Discinacean brachiopods from the Ordovician Kullsberg and Boda limestones of Dalarna, Sweden. Geologiska Föreningens i Stockholm Förhandlingar 109(4), 317-326.

HOLMER, L.E. 1989. Middle Ordovician phosphatic inarticulate brachiopods from Västergötland and Dalarna, Sweden. Fossils and Strata 26, 1-172.

Holmer, L.E. \& POPOV, L.E. 2000. Lingulata, 30-46. In WILLIAMS, A., BRUNTON, C.H.C. \& CARLSON, S.J. (eds) Treatise on Invertebrate Paleontology, part H, Brachiopoda, Revised, Volume 2: Linguliformea, Craniiformea, and Rhynchonelliformea (part). i-xxx, 1-423. Geological Society of America \& University of Kansas, Boulder \& Lawrence.

Holmer, L.E., POPOV, L.E., StRENG, M. \& MiLler, J.F. 2005. Lower Ordovician (Tremadocian) lingulate brachiopods from the House and Fillmore formations, Ibex area, Western Utah, USA. Journal of Paleontology 79(5), 884-906.

DOI] 10.1666/0022-3360(2005)079[0884:LOTLBF]2.0.CO;2

JEREMEJEV, P. 1856. Geognostische Beobachtungen an den Ufern des Wolchow. Russisch-Kaiserische Mineralogische Gesellschaft zu St. Petersbourgh, Verhandlungen 10, 63-84.

KING, W. 1846. Remarks on certain genera belonging to the class Palliobranchiata. Annals and Magazine of Natural History (series 1) 18, 26-42.

KonevA, S.P. 1986. Novoje semeistvo kembriiskikh bezzamkovykh brakhiopod. Paleontologicheskii Zhurnal 1, 49-55.

KunN, O. 1949. Lehrbuch der Paläozoologie. 326 pp. Schweizerbart, Stuttgart.

KUTORGA, S.S. 1848. Ueber die Brachiopoden-familie der Siphonotretaceae. Russisch-Kaiserliche Mineralogische Gesellschaft zu St. Petersbourg, Verhandlungen 1847, 250-286.

LudvigSEN, R. 1974. A new Devonian acrotretid (Brachiopoda, Inarticulata) with unique protegular ultrastructure. Neues Jahrbuch für Geologie und Paläontologie, Monatshefte 3, 133-148.

MiCKWITZ, A. 1896. Über die Brachiopodengattung Obolus Eichwald. Mémoires de l'Académie Impériale des Sciences de St. Pétersbourg 4, 1-215.

MENKE, C.T. 1828. Synopsis methodica molluscorum generum omnium et specierum earum quae in Museo Menkeano adservantur. 91 pp. G. Uslar, Pyrmonti.

MERGL, M. 1995. New lingulate brachiopods of the Mílina Formation and the base of the Klabava Formation (late 
Tremadoc-early Arenig), Central Bohemia. Věstník Českého geologického ústavu 70, 101-114.

MERGL, M. 2001. Lingulate brachiopods of the Silurian and Devonian of the Barrandian. Acta Musei nationalis Pragae, Series $B$ - historia naturalis $57,1-49$.

ORBIGNY, A. D' 1847. Considérations zoologiques et géologiques sur les Brachiopodes ou Palliobranches. Comptes rendus hebdomadaires des Séances de l'Académie des Sciences 25, 193-195, 266-269.

POPOV, L. 2000. Late Ordovician (Ashgill) linguliformean microbrachiopods from the Bestyube Formation, North-Central Kazakhstan. Geobios 33(4), 429-435.

DOI $10.1016 / \mathrm{S} 0016-6995(00) 80075-3$

POPOV, L., HOLMER, L.E. \& MiLleR, J.F. 2002. Lingulate brachiopods from the Cambrian-Ordovician boundary beds of Utah. Journal of Paleontology 76(2), 211-228. DOI 10.1666/0022-3360(2002)076<0211:LBFTCO>2.0.CO;2

ROWELL, A.J. 1966. Revision of some Cambrian and Ordovician inarticulate brachiopods. University of Kansas Paleontological Contributions, Paper 7, 1-36.

SCHUCHERT, C. 1893. Classification of the Brachiopoda. American Geologist 11, 141-167.

ŠNAJDR, M. 1980. Bohemian Silurian and Devonian Proetidae (Trilobia). Rozpravy Ústředního ústavu geologického 45, $1-324$.

VALENTINE, J.L. 2006. Taxonomic assessment, biostratigraphy and faunal turnover of Silurian-early Devonian linguliformean brachiopods from New South Wales,
Australia. i-xxix, 381 pp. Ph.D. Thesis, Macquarie University, Sydney.

WaAgen, W. 1885. Salt Range fossils, I. Productus-Limestone fossils, Brachiopoda. Memoirs of the Geological Survey of India, Palaeontologica Indica (series 13) 4(5), 729-770.

WILLARD, B. 1928. The brachiopods of the Ottosee and Holston formations of Tennessee and Virginia. Bulletin of the Harvard Museum of Comparative Zoology 68, 255-292.

WRIGHT, A.D. 1963. The fauna of the Portrane limestone, 1: The inarticulate brachiopods. Bulletin of the British Museum (Natural History), Geology 8, 223-254.

WILLIAMS, A. 2003. Microscopic imprints of the juvenile shells of Palaeozoic linguliform brachiopods. Palaeontology 46(1), 67-92. DOI 10.1111/1475-4983.00288

Williams, A., CUSACK, M. \& BUCKMAN, J.O. 1998. Chemicostructural phylogeny of the discinoid brachiopod shell. Philosophical Transactions of the Royal Society of London, Series B 353, 2005-2038.

WILLIAMS, A., LÜTER, C. \& CUSACK, M. 2001. The nature of siliceous mosaics forming the first shell of the brachiopod Discinisca. Journal of Structural Biology 134, 25-34. DOI 10.1006/jsbi.2001.4366

ZIKMUNDOVÁ, J. \& KALVODA, J. 1991. Provisional list of conodonts, 24-25. In GALLE, A. \& HLADIL, J. (eds) Lower Paleozoic corals of Bohemia and Moravia. VI. International Symposium of Fossil Cnidaria including Archaeocyatha and Porifera, Münster, Germany, Excursion Guidebook B3. Westfälischen Wilhelms Universität Münster, Münster. 